\title{
Rock clock synchronization
}

To the Editor - The need for much improved knowledge of the durations and ages of climatic and geological events, such as the Palaeocene-Eocene Thermal Maximum ( 55 million years ago), has become urgent within the Earth science and climate modelling communities. The exact dating and timing of fluxes into and out of the marine carbon reservoir can differentiate between competing hypotheses of climatic change. Highly detailed reconstructions of the Earth's history allow us to assess whether past climatic change can be used as an analogue for the current and future change of ocean acidification and climate. The Earthtime project is an international effort with the goal to further this quest for a well calibrated and stable timescale that will allow more precise dating of rock layers and minerals ${ }^{1}$.

Radioisotopic dating methods have small but significant errors that hinder our ability to assess geologically short-lived climate events. For instance, the most widely used method for the Cenozoic era is ${ }^{40} \mathrm{Ar} /{ }^{39} \mathrm{Ar}$, which has an error of up to $2.5 \%$ and few tie points of known age. Yet, over the last two decades much progress has been made in exploiting the imprint of the Earth's orbital variations in palaeoclimatic records. This has dramatically increased the potential age resolution of approaches like cycle-counting and pattern matching, to less than 40,000 years throughout much of Cenozoic time (the past $\sim 66$ million years, Fig. 1).

Unfortunately, there have been a number of inconsistencies and discrepancies between ages and durations derived from radioisotopic and astronomical dating. What is now needed is a more systematic and coordinated approach to provide a detailed intercalibration of radioisotopic clocks (U-Pb, Ar-Ar methods), the rock standards that are used for these methods, and geological tie-points with astronomical ages. At the same time, Cenozoic palaeoclimatic compilations need to be improved by closing existing gaps, verifying data from single sites and supplementing the database of magneto- and biostratigraphy so we can improve the accuracy of existing age calibrations.

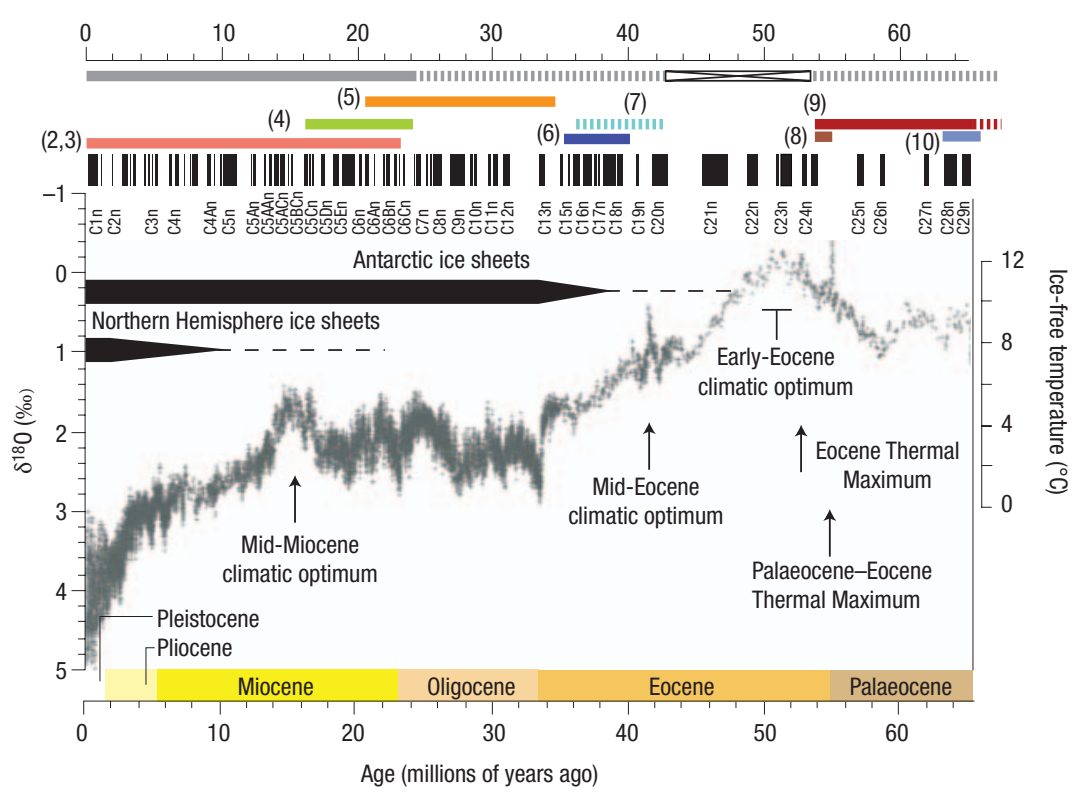

Figure 1 Summary of orbital timescale calibrations for the Cenozoic era in the context of climatic cycles. The upper part illustrates a selection of previous work that resulted in detailed age calibrations for the Neogene and Quaternary ${ }^{2-3}$, and parts of the Palaeogene ${ }^{5-10}$. The uppermost horizontal line indicates a fairly stable and accurate astronomical age calibration with multiple site coverage (solid line), and more tentative or unverified age calibrations (dashed line). There is a significant gap in the middle Eocene (approximately 42 to $53 \mathrm{Myr}$ ago). Age calibrations are shown in the context of an updated multi-site compilation from the Cenozoic of benthic foraminiferal oxygen isotope data ${ }^{11}$, supplemented by the most recent age compilation for magnetic reversals during the Cenozoic ${ }^{2}$. The labels $\mathrm{C} 1 \mathrm{n}, \mathrm{C} 2 \mathrm{n}$, and so on, and respective black bars, correspond to the geomagnetic polarity timescale defined by Cande and Kent using the revised ages from the Geological Time Scale $2004^{2}$.

In particular, a major advance towards a fully astronomically calibrated geological timescale needs to be accomplished in the middle Eocene epoch ( $\sim 40$ to 50 million years). Very few suitable sections have been acquired so far for this period, presumably because the calcite compensation depth was very shallow during this time, which would have prevented the preservation of carbonate material in the deep-ocean marine sediments.

The Earthtime projects are open community efforts aimed at improving intercalibration between astronomical and radioisotope dating methods by finding ash layers that can be dated with radioisotopes within astronomically age-calibrated sections. The immediate aim is to arrive at a highly accurate and stable Cenozoic timescale.
References

1. http://earthtime-eu.eu; http://www.earth-time.org

2. Lourens, L. J. et al. in Geologic Time Scale 2004 (eds Gradstein, F. M., Ogg, J. G., Smith, A. G.) 409-440 (Cambridge Univ. Press, 2004).

3. Raffi, I. et al. Quat. Sci. Rev. 25, 3113-3137 (2006).

4. Billups, K. et al. Earth Planet. Sci. Lett. 224, 33-44 (2004).

5. Pälike, H. et al. Science 314, 1894-1898 (2006).

6. Pälike, H., Shackleton, N. J. \& Röhl, U. Earth Planet. Sci. Lett. 193, 589-602 (2001).

7. Röhl, U., Norris, R. D. \& Ogg, J. G. Spec. Pap. Geol. Soc. Am. 369, $576-589(2003)$.

8. Lourens, L. J.et al. Nature 435, 1083-1087 (2005).

9. Westerhold, T. et al. Palaeogeogr. Palaeocl. 257, 377-403 (2008).

10. Kuiper, K. F. et al. Science (in the press)

11. Zachos, J. C., Dickens, G. R. \& Zeebe, R. E. Nature 451, 279-283 (2008).

\section{Heiko Pälike ${ }^{1}$ and Frits Hilgen ${ }^{2}$}

${ }^{1}$ University of Southampton,

National Oceanography Centre, Southampton,

European Way, Southampton SO14 3ZH, UK;

${ }^{2}$ Department of Earth Sciences, Utrecht University,

Budapestlaan 4, 3584 CD Utrecht, The Netherlands. 